\section{Where Humans are Animals and Animals are Human}

\section{Raghavendra Gadagkar}

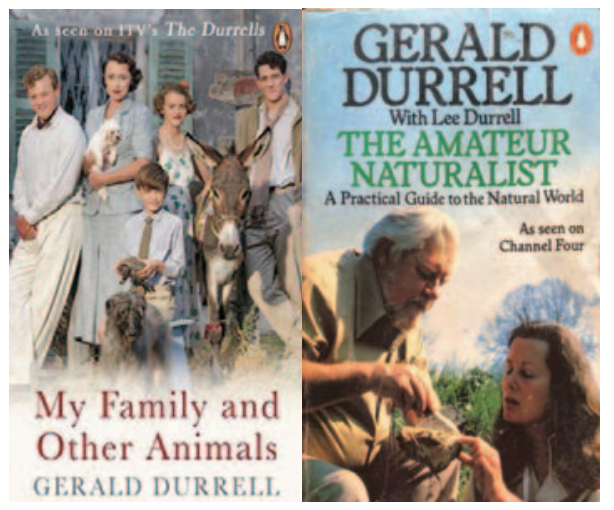

My Family and Other Animals

\section{Gerald Malcolm Durrell (1925-1995)}

Puffin Books 2016

[First Published by in Great Briton

by Rupert Hart-Davis, 1956]

Pages (Paperback): 384 pages

Price (Paperback): ₹ 315

When Tina Jordon, Preview Editor and Columnist at the New York Times Book Review mentioned in the Inside the Book Review podcast on March 9, 2018, that she was reading the very funny book My Family and Other Animals by Gerald Durrell, I was reminded to my embarrassment that I had so far not managed to read this utterly famous book.

I promptly made amends and have had the great pleasure of devouring it in a short span of time. My pleasure was significantly enhanced by the fact that I listened to the audio version, masterfully narrated by the famous British stage, television, and film actor - Nigel Davenport. My Family and Other Animals is indeed incredibly funny but at the same time, it is really inspiring and educational, deserving to be put into the hands of every 10-15year old boy and girl, about the age of Gerald Durrell in the book. I have included an image of Gerald Durrell's The Amateur Naturalist (with his wife Lee Durrell, who of course does not figure in the book under review) alongside an image of My Family and Other Animals so as to contrast in the readers' minds the protagonist as well as the author of the book.

Gerald Durrell was born in Jamshedpur in India in 1925. His family moved back to England in 1928, and he spent five years on the Greek island of Corfu between 1933 and 1939, along with his three siblings and his widowed mother. Free from the burden of formal schooling, Gerald Durrell 'ran wild' and explored the rich natural history of the island in a manner that would have made Darwin proud. In his introduction, Gerald Durrell says:

"This is the story of a five-year sojourn that I and my family made on the Greek island of Corfu. It was originally intended to be a mildly nostalgic account of the natural history of the island, but I made a grave mistake by introducing my family into the book in the first few pages. Having got themselves on paper, they then proceeded to establish themselves and invite various friends to share the chap- 
ters. It was only with the greatest difficulty, and by exercising considerable cunning, that I managed to retain a few pages here and there which I could devote exclusively to animals."

The book itself was written when Durrell was in his 30s and is hence a recapitulation of events past - no mention is made whether it was written from memory or based on a diary. Although he says up front that “... I would like to make a point of stressing that all the anecdotes about the island and the islanders are absolutely true", I got the feeling from time to time that Gerald Durrell was embellishing his stories and conjuring up more funny situations than is fair for any one person to have had the fortune of experiencing. Wikipedia says that "Although My Family is presented as autobiographical, [it is] not completely objective, [and] the events described are not always true". One product description in amazon.com and elsewhere announces that "Gerald Durrell's My Family and Other Animals is a charming and comic autobiographical novel." In any case, I would like to believe that while Gerald Durrell may have embellished his sociology, he did not need to do the same with his zoology. I think there is some evidence supporting my fond belief. Somewhere in the middle of the book he tells us that "He [Peter, his tutor] suggested a diary, but I was against this, pointing out that I already kept one on nature, in which was recorded everything of interest that happened each day." There is yet another, albeit indirect evidence, to support my belief - the robustness and accuracy of his zoological facts in his excellent book The Amateur Naturalist - A Practical Guide to the Natural World. Nevertheless, my belief needs further testing and I propose one. Checking his zoological facts against the literature would make great assignments for students in a course in animal behavior, with the highest grade being reserved for the students who find errors! Be that as it may, I whole heartedly recommend My Family and Other Animals to one and all between the ages of 10 and $>100$.

Gerald Durrell's skill in anthropomorphizing his animals, far from being inappropriate, is really the high point of the book. Some memorable examples are:

"A tiny green grasshopper with a long, melancholy face sat twitching his hind legs nervously. A fragile snail sat on a moss sprig, meditating and waiting for the evening dew. A plump scarlet mite, the size of a match-head, struggled like a tubby huntsman through the forest of moss."

"The new arrival [a tortoise] was duly christened Achilles, and turned out to be a most intelligent and lovable beast, possessed of a peculiar sense of humour... As well as developing a passion for strawberries, Achilles also developed a passion for human company... Achilles would be convinced that you were lying on the ground simply in order to provide him with amusement. He would surge down the path and on to the rug with an expression of bemused good humour on his face. He would pause, survey you thoughtfully, and then choose a portion of your anatomy on 
which to practise mountaineering."

"Owing to his unorthodox upbringing, and the fact that he had no parents to teach him the facts of life, Quasimodo [a pigeon] became convinced that he was not a bird at all, and refused to fly. Instead he walked everywhere. If he wanted to get on to a table, or a chair, he stood below it, ducking his head and cooing in a rich contralto until someone lifted him up... [he] would even try to come for walks with us ... should you get too far ahead you would hear the most frantic and imploring coos and turn round to find Quasimodo running desperately after you, his tail wagging seductively, his iridescent chest pouted out with indignation at your cruelty."

Even more fascinating than his anthropomorphisms are his (and let me now introduce or perhaps coin a new term) 'zoomorphisms' - attribution of animal characteristics or behaviours to humans:

"So we sold the house and fled from the gloom of the English summer, like a flock of migrating swallows."

"...the person I liked best was the old, shepherd Yani, a tall, slouching man with a great hooked nose like an eagle..."

And indeed, the title itself - My Family and Other Animals.

Animal lovers have to make a special effort not to be merely lost in the zoology and ethology in My Family and Other Animals but to pause and savour Gerald Durrell's exquisite prose. Here's an excellent example:
"With March came the spring, and the island was flower-filled, scented, and a-flutter with new leaves. The cypress-trees that had tossed and hissed during the winds of winter now stood straight and sleek against the sky, covered with a misty coat of greenishwhite cones. Waxy yellow crocuses appeared in great clusters, bubbling out among the treeroots and tumbling down the banks. Under the myrtles, the grape-hyacinths lifted buds like magenta sugar-drops, and the gloom of the oak-thickets was filled with the dim smoke of a thousand blue day-irises. Anemones, delicate and easily wind-bruised, lifted ivory flowers the petals of which seemed to have been dipped in wine. Vetch, marigold, asphodel, and a hundred others flooded the fields and woods. Even the ancient olives, bent and hollowed by a thousand springs, decked themselves in clusters of minute creamy flowers, modest and yet decorative, as became their great age. It was no half-hearted spring, this: the whole island vibrated with it as though a great, ringing chord had been struck. Everyone and everything heard it and responded. It was apparent in the gleam of flower-petals, the flash of bird wings and the sparkle in the dark, liquid eyes of the peasant girls. In the water-filled ditches the frogs that looked newly enamelled snored rapturous chorus in the lush weeds. In the village coffee-shops the wine seemed redder and, somehow, more potent. Blunt, work-calloused fingers plucked at guitar strings with strange gentleness, and rich voices rose in lilting, haunting song."

Because he was educated mostly at home and 
by private tutors, Gerald Durrell found it dif- them best sellers. It is difficult to name anficult to get proper jobs, but his talents and other more entertaining, educating and inspirpassion were enough to make him a world- ing book than this timeless classic.

famous zoologist, conservationist, and writer

- he wrote more than 30 books, some of

$\begin{array}{r}\text { Raghavendra Gadagkar } \\ \text { Centre for Ecological Sciences } \\ \text { and Centre for Contemporary Studies } \\ \text { Indian Institute of Science } \\ \text { Bengaluru } 560 \text { 012, India } \\ \text { Email: ragh@iisc.ac.in } \\ \text { http://ces.iisc.ac.in/hpg/ragh } \\ \hline \text { net/profileRaghavendra_Gadagkar }\end{array}$

https://www.researchgate.net/profileRaghavendra_Gadagkar 